\title{
studia
}

\section{Rembrandt i Spinoza. Rozważania o dziejach stylu - odnośnie do problemu baroku}

„Czas nie próżnuje i nie na darmo toczy się jego nurt poprzez nasze doznania; dziwnych rzeczy dokonywa on w duszy”. Przeświadczenie, wyrażone w tych słowach założyciela filozofii dziejów, św. Augustyna ${ }^{1}$, podporządkowuje działanie jednostki prawu czasu, widzi w działaniu indywidualnym oddziaływanie ponadjednostkowej siły.

To, co łączy różnorodne przejawy pewnej epoki, nazywamy jej stylem. Źródłowo, w czysto zewnętrznym sensie, [pod pojęciem stylu rozumiemy to,] że pewne charakterystyczne elementy powracają wciąż przede wszystkim w architekturze epoki. Znajdując wśród elementów budowlanych pełny łuk, mówimy o stylu romańskim, gdy odnajdujemy łuk ostry w konstrukcji budowli innych czasów, mówimy o ostrołukowym stylu gotyckim. Jednocześnie natychmiast można spostrzec, że dążenie stylu nie wyczerpuje się w takich (konstrukcyjnych albo dekoratywnych) cechach sztuk użytkowych, lecz że kształty romańskich tympanonów lub portali gotyckich uformowane są $\mathrm{w}$ tym samym poczuciu stylu, który postaci romańskie zaokrągla, gotyckie wydłuża i zaostrza w ten sposób, że mówić można tylko o jednolitym stylu zarówno w malarstwie, sztukach użytkowych, jak i w tak zwanych sztukach wy-

\footnotetext{
${ }^{1}$ Św. Augustyn, Wyznania, Warszawa 1954, ks. IV, 13. Non vacant tempora, nec otiose voluntur per sensus nostros, faciunt in animo mira opera.
} 
zwolonych. Natychmiast też uświadamiamy sobie, że równieższtuka dźwię$\mathrm{ku}$, jak i sztuka słowa podlega temu samemu prawu stylu. Msza Koronacyjna Bacha tworzy jedność z barokowym kościołem, w którym rozbrzmiewa, wspierając się na fugach niczym na kolumnach, przepełniona światłem świątecznego przepychu, opleciona dekoracyjnymi ozdobnikami². Klasycyzm, który ukształtował majestatyczne fasady Perraulta, rządzi też w treściowym bogactwie tragedii francuskiej. Jest to jedno i to samo odczucie życia, które tu znajduje wyraz $\mathrm{w}$ ukształtowaniu przestrzeni, tam w łączeniu tonów albo w obrazach słownych. Sztuka epoki tworzy pewną konieczną jedność.

Jeżeli rozważa się filozofię lub religię w związku ze sztuką, to dotychczas związek ten uwarunkowany był $\mathrm{z}$ reguły materialnie. Nie trzeba przypominać, że religia swą treścią mityczną wskazuje zadania sztukom plastycznym, a swymi potrzebami kultowymi - sztuce kształtowania przestrzeni, że światopogląd epoki wyraża się w jej poezji. O wiele bardziej istotny, o wiele głębiej bowiem ukryty jest fakt, że ta sama reguła stylu, która rządzi sztuką, włada również filozofią i religią.

Z wzorcową jasnością ukazuje się to w antyku. Antyczna świątynia jest cała obiektywnością, porządkiem, kosmosem, [została] ukształtowana, aby zostać pojęta od zewnątrz jako jedność, w której każda pojedyncza część określona jest przez całość. W takiej samej postawie, jak przed świątynią dorycką, antyczny człowiek staje wpierw w jońskiej filozofii przyrody przed światem - obiektywnie i oczekując jego porządku, a wszelkie odłączenie jednostki jest dla niego upadkiem w grzech; Aischylos tworzy zaś tragedię, która jest jeszcze ciągle sprawą bogów i dotyczy całości świata. Jednakże dzieje świątyń antycznych są dziejami emancypacji kolumny: kolumna dorycka, w Paestum człon całkowicie służebny, wspornik ciężaru, w Partenonie zaczyna ożywać, podobnie jak według systemów świata Heraklita i Parmenidesa, filozofia życia [okresu] przejściowego widzi człowieka w kosmosie, a Sofokles tworzy symbole życia w istnieniu heroicznym, które włącza się w porządek świata. Kolumna jońska budzi się do świadomości, a nawet w Hali Dziewicy Erechtejonu przybiera postać ludzką, sofistyka i sokratyka widzą człowieka na tle świata, stojącego na drugim planie, a los ludzki tworzy Eurypides. W późnym antyku świątynia przestała być obiektywnym istnieniem, rozważanym od zewnątrz: człowiek wszedł do środka, aby tam przeżywać ją od wewnątrz. I tak jak w szybkiej przemianie odczucia życia świątynia stała się strukturą

${ }^{2}$ Por. E. Cohn-Wiener, Entwicklungsgeschichte der Stile in der bildenden Kunst, wyd. 3, Leipzig 1921, t. 1, s. 5 . 
wewnętrzną i została wypełniona uczuciem, tak również świat późnoantycznego człowieka zaczyna być przeżywany od strony subiektywnej. Świat uzyskał dla niego możliwość rozszerzenia się ku bóstwu lub stania się jednością $\mathrm{z}$ bóstwem.

Tajemnicę polaryzacji filozofii takiej, jak św. Augustyna, da się być może zgłębić tylko [w kontekście] dziejów stylu. Filozofia późnoantyczna, taka, jaką jest, żyje całkowicie subiektywnością pojęcia osobowości, swą pewność znajduje w wątpieniu, w woli - zasadę stwórczą, w wolności woli - twórczą siłę osobowości. Ale jednocześnie augustynizm, w przeciwieństwie do plotynizmu, nie ożywia pojęcia osoby do końca, nie aż do Boga. Jednostka zostaje włączona we wspólnotę losu gatunku, który popadł w grzech pierworodny, wolność jej woli została złamana przez predestynację Boga. Nieskończoność późnoantycznego odczuwania zostaje wtłoczona w przymus dogmatycznej praworządności. W taki sposób Hagia Sophia wysklepia kopułę późnoantycznej centralnej budowli, ale nie ponad kołem, krążącym wokół 'ja', lecz ponad mocnymi filarami, które przyjmują kierunek ku ołtarzowi; bazylikowa idea gminy przełamuje biegunowość późnoantycznej idei skupiania w podmiocie i osobie nadaje kierunek oraz cel w ołtarzu, zamiast w nieskończoności.

Architektura romańska podporządkowuje wszystko idei całości i każda część budowli, kolumna, portal, wieża, ma prawo [istnieć] o tyle tylko, o ile prawa tego użycza jej całość. Statyka pełnego łuku oznacza spoczywający w sobie, zamknięty w sobie świat, który jest światem bytu. Romańskie poczucie stylu żyje w uniwersalizmie i w swym myśleniu przyznaje uniwersaliom pierwszeństwo przed każdą jednostkową rzeczą. W przejściowym stylu francuskich katedr i filozofii Abelarda jednostka zgłasza żądanie swego własnego prawa. Szczytowy gotyk wynajduje kompromis między pojedynczą cząstką i całością, przyznając artystycznemu jednostkowemu przedmiotowi jego własną miarodajność na gruncie miarodajności tego, co jest całością, a dzieje się to w tym samym czasie, gdy filozofia szczytowego gotyku ukuła formułę universalia in rebus. Dopiero w indywidualizmie filozofii nominalistycznej, która w podwójnej prawdzie objawienia i poznania nie wymusza już więcej syntezy ostrego łuku, pojedyncza rzecz zaprzecza swej całości, tak jak flamboyant $^{3 *}$ dla indywidualnej samowoli przełamuje ograniczenia uniwersalnej miarodajności.

${ }^{3^{*}}$ Styl we francuskiej sztuce późnego gotyku, charakterystyczny ze względu na bogatą ornamentykę. 
Analogie tego rodzaju można próbować uzasadniać jako grę duchowego bogactwa, dopóki poszukuje się ostatecznych podstaw twórczości artystycznej w sztuce, tworzenia religii - w skłonnościach religijnych, a filozofii w dążeniach poznawczych. W głębi jednak źródłowa, twórcza siła wytwarza z siebie symbole i jest sprawą wtórną, czy należą one do sztuki, czy też do religii albo do filozofii. Nie jesteśmy w stanie scharakteryzować tej twórczej siły, a gdybyśmy chcieli za Heglem nazwać ją duchem absolutnym, to owo nieznane byłoby raczej wyizolowane w sferze tego, co idealne, ale w żaden sposób nie zostałoby wyjaśnione. Pytając o metafizyczne podstawy takiego tworzenia symboli, moglibyśmy znaleźć je w narzuconym ludzkości przymusie, by zagęszczać pewną nieskończoną pełnię w postać, w kształt, by nie zatracać się w nieskończoności i pełni. Tym jednak, co wyznacza każdej epoce jej formę, jest zawsze leżące u jej podstaw odczuwanie życia (das Lebensgefühl), które pozostaje niezmienne bez względu na to, w jakim kierunku by się nie urzeczywistniało. Widzialne przejawy tego odczuwania życia nazywamy stylem epoki, obojętnie, czy spostrzegamy go $\mathrm{w}$ danej epoce jako prawo rządzące w sztuce, religii czy filozofii. Prawidłowość, napotykaną w takiej postaci, moglibyśmy określić jako aksjomat jedności stylu.

Idei jedności stylu można by postawić zarzut, że stwierdzona jedność jest czymś czysto zewnętrznym i ogranicza się do tego, że pewne formalne elementy stylu powracają co prawda w różnych obszarach przejawów kultury, ale że w elementach tych w żaden sposób nie może się zamykać ujawnienie istoty epoki. Jeśli do porównania w postaci paraleli użyć elementów konstrukcji struktury tomizmu, konstrukcji katedry gotyckiej albo gotyckiego cyborium, to łatwo dałoby się pomyśleć, że w przypadku ostatnim przez strukturę architektoniczną wyraża się istota owej woli skonstruowania (der Bauwille), podczas gdy w przypadku pierwszym konstrukcyjnemu stylowi epoki złożona zostałaby tylko ofiara, przy czym jednak systemotwórcza wola epoki zupełnie niezależnie od tego przejawiłaby się w wewnętrznej treści [dzieła]. Temu znów można byłoby odpowiedzieć, że różnica formy i treści nie jest $\mathrm{w}$ obrębie kultury różnicą zasadniczą, a tylko relatywną różnicą stopnia. W sztukach czystej formy, architekturze i absolutnej muzyce, rządzi zasada formy, a wewnętrzna, treściowa określoność musi zostać przez nas dopiero odczytana i wzniesiona do poziomu świadomości za pomocą medium, jakim jest słowo, jeśli pewna wewnętrzna określoność nie jest dana 
absolutnym sztukom przestrzeni i dźwięku przez pomocnicze użycie innych sztuk, plastyki, malarstwa na szkle i malarstwa ściennego w architekturze, a poezji w muzyce. W sztukach takich, jak rzeźba, plastyka i malarstwo, jak również w sztuce poetyckiej określoności formalne i materialne współdziałają z sobą, lecz tak, że wspólne źródło obu jest bez przeszkód widoczne w odczuciu życia epoki. Sztuka romańska, przeniknięta panowaniem absolutu nad wszelkimi partykularyzmami, musi kształtować $\theta$ cotóko $\mathrm{z}$ hieratycznie surowym sędzią świata na jego łonie, gotyk, który pozwala uzyskać absolut $\mathrm{w}$ indywidualnym istnieniu, sadza matkę i dziecko we wzajemnym odniesieniu, w żyjącej grze linii, a dla nominalizmu, który nie zna nic innego poza bytem jednostkowym, rodzaj (das Genre) pozostaje zbędny. Czy należy powiedzieć, że w jednym przypadku mamy ostrość romańskiego prowadzenia linii, a w drugim rządzi rozluźnienie gotyku i że zdarzyło się tak szczęśliwie, iż określony stosunek człowieka do bóstwa pozwolił wyrazić się przez surowość jednego i rozluźnienie drugiego? Albo czy nie należałoby raczej przyjąć, że forma i treść posłuszne są temu samemu podstawowemu prawu? Czas jest siła, która uzewnętrznia się w formie.

Forma w sensie widzialności pewnego stylu zdaje się odgrywać w filozofii nieporównanie mniejszą, aczkolwiek z pewnością nie tak niezauważalną rolę, jak przyjmowano dotąd. Istnieje przecież cały szereg filozoficznych dokonań, przynależących równie dobrze do filozofii, jak i do sztuki, np. dialogi Platona i Bruna, również i cały szereg pism mistycznych średniowiecza, a na koniec Goethe, jeden z najbardziej znaczących filozofów, którego ujawniło myślenie niemieckie, równy rodem każdemu innemu, gdy idzie o działalność historyczną w obszarze czysto filozoficznym. O to, że w takich przypadkach granicznych forma i treść stają się jednym, ponieważ obie wyznaczyła ta sama siła tworząca, nikt prawie poważnie nie będzie toczył sporu. Goethego nauka o metamorfozach jest tylko innym wyrazem tragedii rozwoju Fausta. To jednak, co znaczące w rzadkich przypadkach, gdy w jednej osobie zachodzi unia filozoficzno-artystyczna, musi być również ważne tam, gdzie filozof staje obok artysty. Kto rzeczywiście daje wyraz czemuś określonemu przez swe czasy, czemuś, co w tych czasach jest żywe, czy jak Friedrich Schlegel (jest on również filozofem), który pisać będzie powieści, Schelling (jest też poetą) piszący artykuły i podręczniki albo Runge (który był również teoretykiem) malujący obrazy i wycinający papierowe profile ${ }^{4^{*}}$ : odczucie życia pewnej

$4^{*}$ P. O. Runge (1777-1810), jeden z najwybitniejszych malarzy niemieckich okresu wczesnego romantyzmu, teoretyk (Farbenkugel, teoria trzech barw podstawowych, por. np. J. Gage, 
epoki - zwanej romantyczną - szuka środków wyrazu. We wszelkich typach ekspresji panuje jednak jedność stylu, we wszystkich bowiem formę kształtuje czas.

Jeśli dotychczas istotnym zadaniem dziejów filozofii było rekonstruowanie rozwoju idei, a więc jeśli jej obszar polegał na następowaniu po sobie dziejów, to tutaj zdaje się otwierać perspektywa pewnego nowego zadania, które leży w jednoczesności kultury. Jak odnosi się scholastyka średniowieczna do średniowiecznej sztuki budowlanej, jak mistyka średniowieczna znajduje swój analogon w określonym sposobie myślenia o budowli, z taką samą naukową pewnością musi się dać ustalić, jakiego rodzaju odniesienia łączą scholastykę $\mathrm{z}$ arystotelizmem albo mistykę z neoplatonizmem. A metodykę takich badań rozwinęliśmy do dziś w tak niewielkim stopniu.

Prawo jedności stylu obowiązuje tak dalece, jak daleko sięga jedność kultury danej epoki, tzn. jak daleko ludy włączone są poprzez wspólnotę kulturową we wspólne, ponadnarodowe związki. Nie jest zupełnie niezbędne, by uświadamiać sobie tego rodzaju związek, rozstrzygnięcia zapadają bowiem w podświadomości ludów. Tak to, co w królestwie świadomości jątrząco walczy z sobą, może przecież nosić tę samą formę czasu. Żydzi Zachodu uczestniczą jakoś w romantyzmie i gotyku, a nawet same wojny krzyżowe służyły związkom kultur. Przy czym rozwój stylu dokonuje się nie tylko zgodnie z prawem przyczynowości, lecz również według prawa wzajemnego oddziaływania. Zjawisko stylu, rozpoczynające się w jednym końcu Europy, działa na odległość, jednakże styl zostaje przekształcony przez opór innych tendencji stylu, które napotyka poza miejscem swego pochodzenia i może w zmienionej formie znów powrócić do swojej ojczyzny. Tak było z gotykiem Ile de France, renesansem włoskim, barokiem hiszpańskim, które stały się stylami ogólnoeuropejskimi.

Dziś jeszcze nie mamy zupełnej jasności, gdy idzie o właściwe działanie rozwoju stylu, a przede wszystkim zmiany stylu ${ }^{5}$. Stylu nie wolno zestawiać w żadnym razie $\mathrm{z}$ modą ani traktować pewnego przesytu bodźców jako motywu zmiany. Raczej już należałoby myśleć o skutkach mieszania się krwi i stapiania się ras, które to skutki mogłyby w efekcie prowadzić do zmiany odczuwania życia. W każdym razie nie można byłoby zrozumieć nagłego

Kolor i znaczenie, Kraków 2010, s. 46, 169-176, 187-188), posługiwał się też techniką wycinankową (der Scherenschnitt, Silhouette).

${ }^{5}$ Por. w kwestii zmiany stylu H. Wölfflin, Renaissance und Barock, wyd. 2, München 1907, 2. Abschnitt: Die Gründe der Stilwandlung; tegoż: Das Problem des Stils in der bildenden Kunst, Sitzungsbericht der Kgl. Preuß. Akademie der Wissenschaften, Berlin 1912, s. 572-578. 
zwrotu, jakiego dokona $\mathrm{w}$ antyku hellenizm, bez owego chaosu rasowego, który, przygotowany już wcześniej, wdarł się wraz z wyprawami Aleksandra i który oto cofając się, doprowadził do rozwoju określone strony istoty greckości, wyrażającej się w postaci misteriów. Możliwość pewnego nowego odczuwania życia mogła ukształtować się również w późnoantycznej mieszaninie rasowej Italii.

\section{\&}

Materialistyczne ujęcie dziejów w jego formie ekstremalnej nie posuwa nas wcale dalej, podczas gdy rozwój kultury czyni zależnym od określonych okoliczności materialnych, a świadomość każe określać przez byt społeczny; wówczas bowiem to, co warunkuje zmiany w czynniku materialnym, przejście od jednej formy produkcji do innej, musiałoby być czymś nie-materialnym. Przy dokładniejszych obserwacjach okazuje się, że ta sama siła formująca, która kształtuje ideową nadbudowę, ukształtowała także materialną bazę. Najwyraźniej ten paralelizm formowania ujawnia się w średniowieczu. Średniowiecze określone jest na wskroś przez pewien dualizm, który nie ma, jak na przykład dualizm kultury greckiej, charakteru polaryzacji. Dualizm, który zawładnął średniowieczem, jest wyraźnie dualizmem ostrołuków, tzn. życie średniowieczne, zarówno co do swej kultury, jak i swej struktury społeczno-politycznej, charakteryzuje pewna dwoistość, która nie polega na polaryzacji [elementów] stojących wobec siebie w opozycji, lecz na tym, że jedna $z$ jej części wspiera i niesie tę drugą w zbieżności (Konvergenz). Czy chodzi o Boga i świat, królestwo łaski i sprawiedliwości, papiestwo i cesarstwo, ordo clericus i ordo laicus, albo czy linia Boga i świata biegnie ku ziemskości i zaświatom, niematerialnemu światu i ku naturze, predestynacji łaski i wolności woli, objawienia i nauki, stale znajdujemy ową zasadę, leżącą u podstaw osobliwej jednorazowości gotyckiego sklepienia, a w duszy ludzkiej leży wierzchołek ostrołuku. (Gdy tylko zbiegające się linie stają się jedną, jak kolumna, która śpieszy na spotkanie boskości, średniowiecze się kończy; ale jak wiadomo, równocześnie niewyczerpany jeszcze w swej zasadzie czas epoki wypiętrza linię dominikańską przeciwko linii franciszkanizmu!) Ale także w innych epokach ruchy ekonomiczne albo polityczne zdarzenia dają się wywieść z zasady czasu. Merkantylizm jako system formacji gospodarczej odpowiada w równej mierze tendencji formalnej baroku, jak szkoła fizjokratyczna post-baroku odpowiada powrotowi do natury. A czy sam Wallenstein nie równa się spiralnej kolumnie - niesamowity nakład siły z nikłym rezultatem - a czyż 
wojna trzydziestoletnia nie jest autentyczną wojną barokową? Dokładniejsze badania pozwolą aksjomatowi o jedności stylu przeciwstawić aksjomat drugi - aksjomat paralelizmu: siła, kształtująca epokę działa zarówno w tym, co idealne, jak i w tym, co materialne, ordo idearum idem est ac ordo rerum.

Jeśli porównamy rozwój stylów odległych od siebie epok, możemy spostrzec w nim trzecie prawo, które daje się określić jako aksjomat rytmiki. Dzieje, w przeciwieństwie do zdarzeń natury, są w sobie królestwem jednorazowości, ponieważ są one królestwem wolności. Co tam jest zdarzeniem, tu jest czynem. Dlatego prawa dziejowe, jeśli takie są, muszą różnić się od praw natury tym, że nie odznaczają się one regularnością przebiegających zawsze identycznie linii okręgu, lecz charakteryzuje je regularność spirali. To, że w dziejach w ogóle może być mowa o regularności, uzasadnione jest faktem, iż istota człowieka zakorzeniona jest nie tylko w królestwie wolności, lecz także i w królestwie natury i dlatego rozwój dziejów także w aspekcie kulturowym nie może zaprzeczyć swych naturalnych ograniczeń. W tym, co jednorazowe, prawo oznacza jednorazowość rytmiczną i dlatego prawo trzecie, rządzące stylem, jest aksjomatem rytmiki. Stwierdza się [w nim], że każdy zaczynający się styl jest tektoniczny i związany, że w trakcie swego rozwoju zezwala na swobodę elementów, a kończy się w anty-tektonicznej samowoli gry. Być może u podstaw triady rozwoju stylu widzieć można głębszą polaryzację, polegającą na przeciwieństwie formowania i de-formowania, skończoności (doskonałości) i nieskończoności (niedokończenia). To spolaryzowane przeciwieństwo z doskonałą jasnością ukazuje się $\mathrm{w}$ odniesieniu do przestrzeni. Gdy jedna epoka upatruje właściwe pojęcie wartości w przestrzeni uformowanej, druga widzi swą wartość w nieskończoności. Dojrzały antyk przeciwstawia się w ten sposób antykowi schyłkowemu, romantyzm - gotykowi, renesans - barokowi. I zawsze w rytmie dziejów jedna epoka zastępuje drugą, á $\pi \varepsilon \iota \rho o v$ wczesnego antyku - antyczny $\pi \dot{\varepsilon} \rho \alpha \varsigma$, przełamanie przestrzeni w gotyku wyparło zamkniętość półłuków romańskich, nieskończoność baro$\mathrm{ku}$ - perfectio renesansu'

${ }^{6}$ O poruszonym tu fenomenie pisałem po raz pierwszy w r. $1914 \mathrm{w}$ artykule Barok niemiecki (Frankfurter Zeitung), odnośnie do darmstadzkiej wystawy barokowej, później antytezę klasyka $=$ formowanie, a romantyzm = nieskończoność uzasadniłem $\mathrm{w}$ rozprawie Schopenhauer i romantyzm, w 10. tomie Schopenhauer-Gesellschaft, Heidelberg 1921. Por. ponadto moje 


\section{is}

Życie Spinozy rozpięte jest w ramach, których formę wyznaczył barok. Gdy Spinoza jako dziecko odwiedzał synagogę, odległą ledwie dwa budynki od jego rodzinnego domu, przyjmowała go pałacowa, barokowa budowla, fasada podzielona wielkimi pilastrami i ozdobiona festonami, ukoronowana attyką i przystrojona kutymi w żelazie esami-floresami ${ }^{7}$. Gdy studiował księgi i rękopisy epoki, na przykład „Providencia de Dios” swego nauczyciela Morteiry, jego ręka trzymała zapewne tom, którego skórzaną oprawę warsztat Magnusa pokrył artystycznymi kartuszowymi ornamentami, a na jego złoconych brzegach stylizowane ptaki kołysały się w splątanych pędach wypunktowanych starannie arabesek. Był zadomowiony w barokowej literaturze Hiszpanii: czytał dzieła Gongorasa, twórcy barokowego manieryzmu, wspominał jego losy w uwadze do Etyki ${ }^{8}$. Łóżko, które zatrzymał w spadku po ojcu, stało na toczonych kuliście barokowych nóżkach, a para srebrnych sprzączek, które pozostawił, ozdobiona była zapewne dynamicznie barokowymi splotami. Barokowej modzie posłuszne były jego włosy, opadające na ramiona i obramowujące spiralnymi skrętami oliwkowej barwy twarz. (Czasy peruk z długimi włosami jeszcze nie nadeszły.) Kościół, w którym znalazł się jego grób i w którego krypcie jego szczątki zjednoczyły się z ziemią, jest na gruncie holenderskim największym architektonicznym dziełem baroku. Czy mamy uwierzyć, że barok uformował jedynie ramy, obejmujące to życie? Wówczas epoki byłyby rzeczywiście puste i przechodziłyby przez nasze życie nie zostawiając w nim śladów.

Pytanie o relacje między Rembrandtem i Spinozą dopiero teraz może ujawnić swą heurystyczną wartość. Oczywiście należy przy tym wpierw rozstrzygnąć problem, czy Rembrandta w ogóle zalicza się do baroku, czy też nie. Wölfflin sięga po niego bez wahania, by na przykładzie jego sztuki zademonstrować kategorie konstytutywne dla baroku: „Rembrandt, Velasquez i Bernini, przy całej odmienności, krążą wokół wspólnego centrum”, a Rembrandt tak samo jak Rubens uczestniczy jego zdaniem „w barokowym principium”10.

wprowadzenie do Schopenhauer und Brockhaus, zur Zeitgeschichte der Welt als Wille und Vorstellung, Leipzig 1926.

${ }^{7}$ Por. rycinę w Chronicon Spinozanum I, s. 267.

${ }^{8}$ Jak widzę, do dziś nie wyjaśniono, kim jest „Hispanus Poïta”, o którego utracie pamięci wzmiankuje Etyka, cz. IV, tw. 39, schol.

${ }^{9}$ H. Wölfflin, Kunstgeschichtliche Grundbegriffe, München 1915, s. 36.

${ }^{10}$ Tamże, s. 101. 
W podobnym sensie wypowiada się o nim Hausenstein: „Jego wkład do baroku jest nadzwyczajny, jego pochodzenie z baroku - oczywiste" ${ }^{11}$. W przeciwieństwie do tego najgłębszy znawca Rembrandta w Niemczech, Carl Neumann, zasadniczo odrzuca to przyporządkowanie go do stylu baroku jako „kolektywistyczno-pozytywistyczną filozofię dziejów, jako zmechanizowanie duchowości, grubiańskie zaszufladkowanie i prostacką syntezę"12, a jednocześnie prawie zupełnie pozbywa się pojęcia baroku (wydobywając w jego miejsce ciągłość działania renesansu).

Z góry dodać należy, że nie jest możliwe, by zjawiska duchowe podporządkować bez reszty jakiemuś „systemowi Linneusza”, podobnie jak nie jest możliwe wyizolowanie i odgraniczenie w kulturze grup, to znaczy okresów czasu. W strumieniu dziejów jedne koniecznie przechodzą w drugie. Ale czy $\mathrm{z}$ tego powodu, że nie wiadomo, jak rozstrzygnąć, czy Giotto należy już do renesansu, albo Botticelli jeszcze do gotyku, Michelangelo już do baroku, a Hannibale Carracci jeszcze do renesansu, należy zlikwidować samo pojęcie renesansu? Filozoficzny sposób rozważania wymaga jedności pośród różnorodności, przy czym jesteśmy w pełni świadomi faktu, że jedność ta ugruntowana jest zarówno w przedmiocie, jak i w podmiocie rozważań. Jeśli wiek XIX wykrył w wieku XV pokrewne własnemu odczucie życia i stworzył pojęcie „renesansu”, to nasze czasy chciałyby sobie zastrzec [prawo] wypełnienia XVII-wiecznego odczuwania życia i kontynuując dzieło poprzedników, ukształtować jego jedność w [postaci] „baroku”.

Leone Battista Alberti wyjaśnił istotę architektury swoich czasów, a tym samym podał formułę sztuki renesansu, a wręcz stylu jego bytu w ogóle, jako concinnitas $^{13}$. Znaczenie tego pojęcia najlepiej oddaje die Geformtheit, uformowanie, foremność. Alberti zdefiniował je jako „ograniczenie (finitio), wewnątrz którego linie dające się zmierzyć odpowiadają sobie" ${ }^{14}$. Do istoty owej harmonijnego ograniczenia Alberti wlicza to, że „nic nie może zostać dodane, odjęte ani zmienione, nie zagrażając całości" i podaje wskazówkę, by „Wszystko podporządkować kątom, określonym równymi liniami” ${ }^{15}$. Piękno

\footnotetext{
${ }^{11}$ W. Heisenstein, Vom Geist des Barock, München 1924, s. 95.

${ }^{12}$ C. Neumann, Rembrandt, 4. Aufl., München 1924, s. 544-594: Rembrandt und der Barockstil.

${ }^{13}$ De re aedificatoria VI: Nos tamen sic definiemus: ut sit pulchritudo certa cum ratione concinnitas universarum partium in eo cuius sint: ita ut addi aut diminui aut immutari possit nihil quin improbabilius reddat.

${ }^{14}$ Tamże, IX: correspondentia quaedam linearum inter se, quibus quantitales dimentiantur.

15 Tamże, VI: omnia ad certos angulos paribus lineis adaequanda.
} 
jest dla niego „zgodnością części”16 i jest pewien, że zgadza się z tym również natura jako najlepszy artysta ${ }^{17}$ : ,także i to, co wytwarza natura, stale kształtowane jest zgodnie z zasadą foremności i nie ma w naturze silniejszego dążenia jak to, by wszystko, co ona rodzi, było doskonale wykończone"18.

Jeśli najgłębszą istotą renesansu jest „foremność” (concineitas), jej środkiem - „ograniczenie” (finitio), a jej celem - doskonałość (perfectio), to najgłębsza istota baroku znajduje się w biegunowym przeciwieństwie do niej. Gdy nie zadowolimy się tym, by charakterystyczne cechy baroku wydobywać empirycznie z jego budowli, rzeźb i malarstwa, jako czyste, zebrane pośpiesznie kategorie (w sensie Kantowskim) ${ }^{19}$, gdy się je chce sprowadzić raczej filozoficznie do jedności pewnej podstawowej zasady, to taką podstawową kategorią baroku jest nieskończoność; z niej bowiem pozwalają się wywieść wszelkie kategorie baroku, wyjaśnić wszelkie jego fenomeny.

\section{is}

Nieskończoność baroku ujawnia się w trzech kategoriach de-formowania (die Entformtheit), substancjalności i potencjalności.

De-formowanie baroku oznacza, że $\mathrm{z}$ istoty neguje on granice tam, gdzie je ustanowił renesans. Organem, którym kształtuje renesans, jest zmysł dotyku, wymierzający granice rzeczy i z tego powodu do rzeczy przylegający. Organem, którym tworzy barok, jest oko, które jako funkcja czuwającego [umysłu] nigdy nie spoczywa i dlatego właśnie ma nieskończoność funkcji. Jeśli renesans tworzy, to tworzy w poczuciu ciała: uformowana postać, statua, jest jakby prafenomenem jego sztuki; jego przestrzenie formowane są i ograniczane $\mathrm{z}$ odczucia ciała, jego obrazy sporządzone są $\mathrm{w}$ zamkniętej formie $\mathrm{z}$ tworzywa koloru. Styl renesansu jest stylem plastycznym ${ }^{20^{*}}$. W przeciwieństwie do niego prafenomenem baroku jest obraz, który zdolny jest przede wszystkim budzić iluzję nieskończoności i dlatego jego styl jest stylem ma-

\footnotetext{
${ }^{16}$ De re aedificatoria IX: Quae si saris constant, statuisse sic possumus pulchritudinem esse quendam consensum et conspirationem partium in eo cuius sunt ad certum numerum finitionem collocationemque habitam ita ut concinnitas hoc et absolutu primariaque ratio naturae postularit.

17 Tamże, IX: optima artifex.

${ }^{18}$ Tamże: Quidquid enim in medium proferat natura, id omne ex concinnitatis lege moderatur, neque studium est maius ullum naturae quam est quae produxerit absolute perfecta sint.

${ }_{19}$ Tak uważa H. Wölfflin, zob. Kunstgeschichtliche Grundbegriffe, s. 238.

$20 *$ Tu: wypukłym, bryłowatym, przestrzennym, dającym się modelować.
} 
larskim. Gdy barok tworzy statuę, to tworzy ją po malarsku, nie pozwalając, by nieskończoność pozbawionej form postaci zastygła w ograniczeniu jednej tylko formy - w ujęciu z profilu, od frontu, $\mathrm{z}$ tej lub $\mathrm{z}$ innej strony - lecz świadomie ukazuje wzburzenie jej luźnych zarysów i świadomie nie określa miejsca, z którego należy ją oglądać. Tworząc przestrzenie, wobec których nie może się powstrzymać, by nie ograniczyć ich ścianami i dachami, barok każe ich istotnym częściom znikać w ciemności niszczącej formy, gdzie może, tam przełamuje zamknięcia rozpuszczającym formy światłem, głoszącym nieskończoność, spiętrza kopuły, wszelkie linie cykloidalne oznaczają bowiem minimum granic, a w kopułach umieszcza latarnie, ściany i stropy rozpuszcza wręcz, pokrywając je obrazami iluzyjnymi, które zamieniają nieskończoność $\mathrm{w}$ przestrzeń, aż wreszcie ( $\mathrm{w}$ czasach Berkeleyowskiego idealizmu) rokoko swymi ścianami luster sprawia, że przestrzeń ulatnia się w grze iluzji wrażeń.

Same obrazy baroku nie są, jak obrazy renesansu, uformowanymi płaszczyznami, na których doskonałe wykończenie całości powstaje z ograniczonych pojedynczych części, lecz są przede wszystkim iluzją przestrzeni, to znaczy zamierzoną nieskończonością. Ich kompozycja nie jest zakomponowaniem płaszczyzny, lecz głębi, a służy ona w równej mierze zapełnieniu pierwszego planu, jak i zaaranżowaniu perspektywy. Również kościół barokowy rozlokowany jest w perspektywie głębi i działa wszelkimi środkami perspektywy, gdy idzie o przecięcia i prowadzenie światła. $Z$ chęci deformowania, diametralnie przeciwstawnej wobec renesansowej woli kształtowania, widać, że barok kocha niejasność, tak jak renesans ukochał jasność. To, że w końcu wraz $\mathrm{z}$ barokiem powstaje pejzaż, który odgrywał w renesansie jedynie podrzędną rolę, współzależy właśnie od tego, że pejzaż jest jakby przypadkowym wycinkiem nieskończoności, podczas gdy istniejąca sama dla siebie forma postaci ludzkiej z istoty swej przeczy deformacji. Jeśli renesans definiuje piękno jako współbrzmienie części (conspiratio partium) i znajduje w nim urzeczywistnioną ratio naturae, to piękno baroku jako piękno nieograniczonych form jest zupełnie irracjonalne. Jakaż bowiem liczba byłaby bardziej irracjonalna niż $\infty$ ?

Do istoty nieskończoności należy to, że jest niepodzielna. Wiedzę o tym uzyskał już późny gotyk Mikołaja z Kuzy, a wczesny gotyk Giordano Bruna odnowił ją. Dlatego drugą kategorią baroku jest substancjalność, zgodnie z którą wszelkim bytom jednostkowym przysługuje tylko istnienie warunkowe, podczas gdy prawdziwe istnienie właściwe jest tylko nieskończonej całości albo (inaczej mówiąc i przez wzgląd na rzeczy jednostkowe): istnieje tylko substancja. 
Tam, gdzie renesans z wydzielonych pojedynczych części ukształtował zamkniętą w sobie i oddzieloną od pozostałego świata całość, barok daje już tylko fragment nieskończonego; istota tego fragmentu tkwi właśnie w związku z owym nieskończonym. Obraz na płótnie jest wtłoczonym w ramy kawałkiem nieskończoności, statua - wirem strumienia nieskończoności, płynącego przez barokowy kościół, a sama przestrzeń kościoła, obejmująca obraz przy ołtarzu i rzeźby - niczym innym, jak „naczyniem nieskończoności”21. W baroku nic nie jest dla siebie, wszystko ma swój właściwy świat poza sobą, a w świecie skończoności pojawia się wysłany tylko jako głosiciel tamtego, właściwego świata nieskończoności. Także i dziś, gdy napotykamy jakieś [pojedyncze] barokowe dzieło pozbawione związku z całością świata ówczesnej sztuki, to świat ten i tak niewidzialnie rozpościera się wokół niego na podobieństwo jakiejś metafizycznej atmosfery: jako jednostkowa rzecz, dzieło jest niczym, a swe znaczenie uzyskuje dopiero w związku współzależności. Czyż nie jest symptomatyczne, że wczesny barok chciał malować tylko fale, a morze udało się przedstawić dopiero barokowi? Także i pejzaż jako jedność, przeniknięta życiem natury, pagórek i drzewo, rzeka i chmura ujęte w jednym, jednolitym życiu, dany był do namalowania dopiero barokowi. Tak jak w składniku materialnym, tak też i w formalnym nic nie posiada własnego istnienia; również barwa wydobyta jest tylko z ruchu obrazu, także i forma dobywa się z potoku tego jednego wielkiego ruchu. Przede wszystkim jednak jako czynnik tworzenia służy barokowi światło - w równej mierze w malarstwie, plastyce i architekturze. Światło jako czynnik twórczy współdziała w baroku z jego czynnikiem receptywnym, z okiem. Świat baroku żyje w świetle i ciemności, są one obydwiema stronami tej samej rzeczywistości. Światło wnosi w wielość motywów jedność, rytmiczną, a nie plastyczną.

Ważne jest oto, że kategorie, konstytuujące relację między modalnością a substancjalnością, nie zostały po prostu $\mathrm{z}$ racji subiektywnego wyboru imputowane w świat barokowy; mogłyby to poświadczyć sformułowania, które dla relacji tej już zostały znalezione: „Barok nie liczy się już zasadniczo z pewną wielością samodzielnych części, które harmonijnie współujmuje, lecz z pewną absolutną jednością, w której pojedyncza część utraciła swe odrębne prawa ${ }^{22}$ ”. „Od początku istnieje tu jedno powszechne poczucie, że każ-

${ }^{21}$ W. Hausenstein, Vom Geist des Barock, s. 85: „Unendlichkeit des Innern ist in Gefäß gefangen” (Nieskończoność tego, co wewnętrzne, ujęta jest naczyniem).

${ }^{22}$ H. Wölfflin, Kunstgeschichtliche Grundbegriffe, s. 165. 
da istota mogłaby mieć sens i znaczenie dopiero $\mathrm{w}$ związku $\mathrm{z}$ innymi, $\mathrm{z}$ całym światem"23. „Jest tak, jakby wszystko było z jednego tworzywa”24.

Trzecią konstytutywną kategorią baroku jest potencjalność. Nieskończoność w zjawisku jest zawsze tylko potencjalnie; gdyby była aktualnie, nie zdołałaby być nieskończonością. Dlatego styl baroku, w przeciwieństwie do stylu klasycznego, nie jest stylem bytu, lecz stylem stawania się i dziania się. Barok jest sztuką podróżnych: oglądający, widz nie stoi przed gotowym faktem, lecz jak gdyby przypadkowo bierze udział w jakimś zdarzeniu. Barok nie chce, by zdarzenie zamarło w ostatecznej postaci; stąd obserwowana w nim obawa, by nie wypowiedzieć „ostatniego słowa” ${ }^{25}$. Dlatego też, ze względu na jej jednoznaczność, unika się również klarowności, a poszukuje niejasności, która zawiera w sobie możliwość różnorodności. Styl klasycznej faktyczności i jawności jest stylem istnienia, dlatego jest stylem statycznym, zaś styl stawania się i dziania - stylem potencjalnym, dlatego dynamicznym. Siła nie oznacza dla baroku spoczywania w sobie, lecz natężenie, które uczyniono widocznym: spiralna kolumna jest symbolem baroku, wije się w niesamowitym wytężeniu, aby dźwigać. Tam, gdzie jest barok, tam panuje napięcie, uzewnętrzniające się $\mathrm{w}$ asymetrii części, nienasyceniu, irracjonalności proporcji. Dynamika jest ruchliwością, dlatego najskrajniejsza ruchliwość panuje w baroku pod każdym względem, w kompozycji obrazów, w zarysie rzeźb, w fasadach barokowych budowli. Wrogi wszelkim liniom prostym, wybiera krzywizny pofalowane przez dynamikę, rozciąga koło w owal albo wykręca je w spiralę. Kocha możliwości, a nie rzeczywistość; dlatego używa przypadkowości (Bernini nazwał przypadek (caso) współtwórcą swego głównego dzieła), owej przypadkowości konkretu (des So-Seins), która może obrócić się również w inno-byt. Jeśli renesans był stylem budowniczych ${ }^{26}$, mechanistycznym w obliczaniu swej statyki, to barok jest stylem organicznym ${ }^{27}$, odczuwającym i tworzącym życie, organicznie, już ze swej substancjalności oznacza jedność w wielości, wielość w jedności, co zawsze było cechą życia organicznego. Ten organiczny rys podstawowy przenosi równocześnie rysy naturalistyczne, które charakteryzują barok; jedynie bowiem forma natury zawiera prawidłowość potencjalności, dążenia do urzeczywistnienia, które nigdy nie kończy się w czymś ostatecznie ważnym. Potencjalność to skala nieskończonych przebiegów,

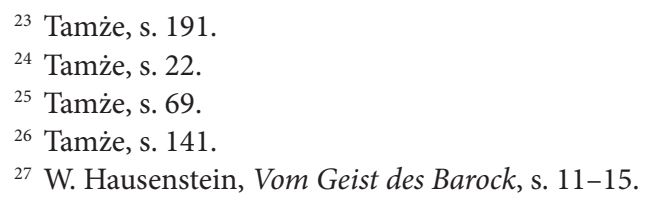


a nie kierunkowskaz połączonych stopni. Stąd nieustrukturowanie w baroku, stąd jego ruch mas, jego wzbieranie i opadanie. Sztuka przechodzenia jest sztuką niuansów. Z podwójnego źródła naturalizmu i niuansowania wyrasta to, co barok podarował światu jako nowość: psychologia. Żadna sztuka czasów wcześniejszych nie potrafiła ująć duszy jako potencjalności, jako lustra owych nieskończonych ruchliwości i półtonów, które kołyszą się między biegunami rozkoszy i śmierci. W obszarze metafizyki potencjalność baroku wznosi się w dynamice światła i cienia. Barokowa ciemność to spokój, będący możliwością wszelkich poruszeń, światło zaś, falując w formach, przelewając się przez nie, lśniąc w barwach i pochłaniając je, jest protuberancją nieskończonego w królestwo możliwości.

Mówić o Rembrandcie, jako wyrazicielu twórczej siły jego czasów, znaczy chcieć wyczerpać niewyczerpalne. Ma się wówczas uczucie, jakie nawiedziło św. Augustyna wobec chłopca, który chciał swoją łyżeczką wyczerpać morze. Irracjonalności tego, co twórcze, racjonalność odmawia pojęć.

Giordano Bruno ujął pewnego razu poczucie życia nowożytności, którego jest wyrazicielem, słowami: „Kochajcie kobietę, jeśli chcecie, lecz nie zapominajcie być czcicielami Nieskończonego". Rembrandt stał się prawdziwym czcicielem nieskończoności, mógł stworzyć formę kobiety, obudzić życie pejzażu, mógł w religijnym działaniu tęsknoty odnaleźć i nadać jej symbol. Kategorie nieskończoności są także kategoriami sztuki Rembrandta.

Sztuka Rembrandta nie dąży, jak sztuka Dürera lub Rafaela, do ukształtowania formy drogą ograniczania - ona zmierza do od-formowania. Nie jest linearna albo plastyczna, lecz z istoty swej malarska. Nigdy nie interesuje jej rozjaśnianie i ustalanie pojedynczej formy, raczej używa jej tylko jako litery pewnego pisma, które opisuje tajemnicę tego, co nieuformowane. Dlatego $\mathrm{w}$ wielu rycinach wykonanych piórkiem, a przede wszystkim w rysunkach, forma ma uwarunkowany w ten sposób charakter rękopisu. Od-formowaniu służy Rembrandtowskie światło, które nigdy nie ma postaci ustalonej, nigdy też nie jest użyte w sensie klasycznym, dla wypracowania połączeń form. Najjaskrawszym przykładem tego wewnętrznego odformowania obrazu jest Nocna warta. Jeśli wiek XVI w Niderlandach zbudował portret grupowy z zestawienia postaci obok siebie, a doskonaląc go, ujednolicił przez zademonstrowanie jakiegoś wspólnego przedsięwzięcia grupy, to tutaj wynaleziona już forma zostaje rozbita światłem poprzez akcentowanie w nim tego, 
co (w sensie obrazu) nieistotne. Przy obrazie tym niezbędna jest sugestia, że chodzi o dzieło światowej sławy, aby temu, kogo nie przybliżyło doń przeżycie baroku, umożliwić jego przeżycie artystyczne. Także rozwiązania barw lokalnych uwarunkowane są barokowym od-formowaniem. Barwy Rembrandtowskie żyją swoim własnym życiem; ani nie przedstawiają form rzeczy, ani nie artykułują kompozycji, są raczej rozbłyskiem albo rozżarzeniem owej nocy nieskończoności, z której wzniosła się Rembrandtowska wizja. Podobnie też w niepoznawalnym znikają formy, ponieważ Rembrandtowski obraz ma swoje wibrujące życie w od-formowaniu całości. Również płaszczyzna jako scena form zostaje zanegowana w sensie barokowego tworzenia głębi, symetrii konstrukcji frontalnych unika się na korzyść deformującej asymetrii, którą dość często posługuje się diagonalność baroku. Charakterystyczna jest substancjalność sztuki Rembrandta: wszystko, co jednostkowe, jest w niej jedynie odmianą jednej wszechogarniającej substancji. Rzeczywiście jest tak, jakby wszystko było u niego tylko $z$ jednego tworzywa. Nie jest przypadkowy najbardziej bezpośredni wyraz Rembrandtowskiej sztuki sztychu. Sztychownik siedzi nad okopconą sadzą płytką miedzianą i wycina swoje kreski w sadzy, tworzy z kreskowań kompleksy, pracując dzięki jedności pewnej wizji, którą technika pozwala mu przenieść natychmiast w zjawisko. Dlaczego Rembrandta nie można wyobrazić sobie pracującego nad drzeworytem, tylko nad miedziorytem? Ponieważ właśnie łączący formy drzeworyt jest wyrazem klasycznego poczucia sztuki, które stawia rzecz obok rzeczy, gdzie natomiast barok zna tylko jedność wizji, jedność substancji świata. Jeśli Rembrandt maluje pewną scenę w świątyni, to wzgórze albo draperia odbierane są jako nie mniej kapłańskie niż wyciągnięta ręka Symeona. Wszystko, nawet jeśli w różnym stopniu, jest uduchowione. W obrazach Rembrandta nie istnieje różnica między tym, co główne i akcydentalne; wszystko wyraża sens całości i jest tak, jakby całość była w najmniejszej cząstce. Jest to owa substancjalność, która obrazom Rembrandta nadaje jedność, która nie jest jednością formalną, lecz wydaje się jednością metafizyczną.

Jest tak, jakby każda epoka miała sobie właściwą formę dualizmu. Jeśli dualizmem określającym styl gotyku był dualizm ostrołuków, to dualizmem baroku jest dualizm potencjalności. I tu, i tam jest dualność, dążąca do jedności, ale tam - mamy jedność wielostronnego dźwigania i wspierania się, tu - jedność stopniowego przechodzenia, jedność skali. Potencjalność w sztuce Rembrandta okazuje się dla wrażeń oka potencjalnością światła. Rembrandtowska dynamika jest istotnie dynamiką światła. Jeśli dynamika ruchu była cechą baroku, to oczywiście również i Rembrandt bierze udział w tym baro- 
ku ruchu (we wcześniejszych jego obrazach z upodobaniem do pasażowania, chyba jeszcze większym niż w późniejszych płótnach); decydujące jest jednak dla niego stawanie się i zmiana wrażeń świetlnych, której dynamika neguje wszelką statykę bytu. Obraz Rembrandta zrodzony jest z ciemności, ale z ciemności, która jest możliwością wszelkiego światła, tak jak spokój baroku oznacza możliwość każdego ruchu. Z tej zawsze potencjalnej, a nigdy aktualnej ciemności wznoszą się jego wizje świetlne. Nie jest to żadne biegunowe, manichejskie przeciwieństwo, żadna walka między światłem i ciemnością, lecz wznoszenie się z najciemniejszej nocy ku najradośniejszemu światłu. Nieskończoność ukryta w mroku, w świetle zmierza ku swej widzialności.

\section{is}

Czy konstytutywne kategorie baroku, które można ukazać jako konstytutywne dla sztuki Rembrandta, wzniosły się do [poziomu] świadomości $\mathrm{w}$ podstawowych przeświadczeniach filozoficznych spinozyzmu? Jedynie przy takiej zgodności, sięgającej aż do samego dna głębi, można się odważyć uznać spinozyzm za filozoficzny wyraz barokowego odczucia życia.

Nie trzeba dowodzić, że spinozyzm jest filozofią nieskończoności; nieskończona substancja jest jego najwyższym pojęciem i najwyższą wartością. Ale również te trzy podstawowe kategorie baroku dają się z niego wywieść jako podstawowe przeświadczenia spinozyzmu.

Prawu de-formowania Spinoza nadał jego klasyczne piętno: omnis determinatio est negatio. „Co do tego, że kształt jest zaprzeczeniem, nie zaś czymś pozytywnym, to jasne jest, iż materia w całości, rozważana jako coś nieokreślonego (onbepaaldelijk aangemerkt) nie może mieć żadnego kształtu, a kształt przypisany jest wyłącznie ciałom skończonym i ograniczonym. Jakoż ten, kto powiada, że spostrzega jakiś kształt, chce przez to tyle tylko zakomunikować, że spostrzega jakąś rzecz ograniczoną oraz sposób, w jaki jest ona ograniczona. Ograniczenie to nie należy do rzeczy ze względu (naar) na jej byt, ale przeciwnie, jest ono niebytem tej rzeczy. Skoro tedy kształt nie jest czym innym, jak ograniczeniem, a ograniczenie jest zaprzeczeniem, to i kształt, jako się rzekło, nie może być niczym innym, jak zaprzeczeniem"28.

Kto poprawnie rozumie to zdanie, tego, gdy je czyta, ogarnia zgroza, tak jakby spoglądał w przepaść.

${ }^{28}$ Listy mężów uczonych do Benedykta de Spinozy oraz odpowiedzi autora wielce pomocne dla wyjaśnienia jego dzieł, Warszawa 1961, Ep. 50, s. 232. 
Der Abgrund meines Geists ruft immer mit Geschrey

Den Abgrund Gottes an: Sag welcher tieffer sey ? $^{29}$

Spinoza nie użył w Etyce skrajnego sformułowania $\mathrm{z}$ tego listu, ale nauka o od-formowaniu tego, co absolutne jest właściwa także dla Etyki, gdzie uczy ona, że „skończoność (finitum esse - dosł. bycie skończonym) jest w rzeczywistości częściowym zaprzeczeniem, nieskończoność zaś bezwzględnym potwierdzeniem istnienia jakiejkolwiek natury" ${ }^{30}$.

To, że nauka o substancjalności należy do podstawowych przekonań spinozyzmu, jest oczywiste i zostało wyrażone w przyporządkowaniu pojęć substancji i modyfikacji. Substancja jest w sobie i pojmuje się ją przez nią samą, podczas gdy modus jako pobudzenie substancji jest w czymś innym ${ }^{31}$. Wszystko jednak jest w Bogu i wszystko, co się dzieje, wynika z jego istoty $^{32}$, on jest immanentną przyczyną wszystkich rzeczy, zarówno ich istoty, jak $\mathrm{i}$ ich istnienia ${ }^{33}$, poszczególne rzeczy nie są niczym innym, jak pobudzeniem atrybutów Boga, sposobami, w jakie atrybuty Boga w pewien określony sposób zostają wyrażone ${ }^{34}$ i tylko przez Boga rzeczy mogą zostać wyznaczone do działania ${ }^{35}$. Natura tworząca jako będąca-w-sobie ujawnia się w naturze stworzonej jako całościowość przejawów Boga ${ }^{36}$. Ciało i duch są tylko o tyle, o ile wyrażają istotę Boga, a owa identyczność pewnego sposobu rozciągania się i sposobu myślenia, którą nazywamy człowiekiem, właściwie również nie jest bytem substancjalnym, lecz tylko modalnym ${ }^{37}$. Tak jak żadna rzecz jednostkowa nie ma swego bytu z siebie samej, tak też i nie może być poznana przez nią samą, lecz tylko poprzez poznanie boskiej natury jako prawdziwej realności ${ }^{38}$. A także wszelkie jednostkowe myślenie jest prawdziwe jedynie

${ }^{29}$ Angelus Silesius, Cherubinischer Wandersmann. („Duchowa otchłań ma wciąż o odpowiedź prosi, / Która z nas głębsza jest? - do boskiej okrzyk wznosi." Anioł Ślązak, Cherubowy wędrowiec, Mikołów 2000, fragm. 68, s. 26.)

${ }^{30}$ B. de Spinoza, Etyka, Warszawa 1954, cz. I, tw. 8, przyp. 1, s. 9-10.

31 Tamże, def. 3 i 5, s. 3-4.

32 Tamże, przyp. do tw. 15, s. 27.

${ }_{33}$ Tamże, tw. 18, s. 33, tw. 25, s. 38.

${ }^{34}$ Tamże, dod. do tw. 25, s. 39.

35 Tamże, tw. 26, s. 39.

${ }^{36}$ Tamże, przyp. do tw. 29, s. 43. „...als Gesamtheit der Weisen Gottes” - Gebhardt przekłada tu modus (sposób, przejaw, odmiana) jako die Weise, „sposób”. „Całościowość sposobów Boga” po polsku brzmi wyjątkowo niejasno, więc korzystam z propozycji I. Halperna-Myślickiego i tłumaczę to pojęcie jako „przejaw”.

${ }^{37}$ Tamże, cz. II, def. II, s. 63, tw. 10, s. 76.

38 Tamże, dod. do tw. 11, s. 79. 
jako uczestniczenie w nieskończonym rozumie Boga ${ }^{39}$. Z przekonania o substancjalności Boga wynika również etyczne żądanie substancjalności: co jest częścią Boga, powinno chcieć być jego częścią.

Trzecia kategoria baroku, potencjalność, ujawnia się w taki sam sposób jako podstawowy charakter spinozyzmu: [pozostaje] zaciemniona oczywiście dopóty, dopóki przez analogię do matematyki próbuje się w spinozyzmie dostrzec jakąś metafizyczną geometrię bytu. Istota Boga to actuosa essentia ${ }^{40}$, a dynamika tego centralnego pojęcia wypełnia każde pojęcie cząstkowe. Dla Descartes’a rozciągłość była wypełnieniem przestrzeni, dla Spinozy rozciągłość, której utożsamienie z materią jest sporne $\mathrm{e}^{41}$, nie jest wypełnieniem przestrzeni, lecz ruchem i spoczynkiem ${ }^{42}$. Jest to tak, jakby statyczne odczucia renesansu, zachowane w klasycyzmie baroku francuskiego, tutaj zostały zamienione w dynamiczną zasadę baroku. I jak siła jest istotą ciała, rozwijającą się w stopniowalności ruchu i spoczynku, tak też jest ona również istotą idei, które nie są nieme jak obrazy na tablicy ${ }^{43}$, lecz które pojmują i potwierdzają się. Owo samopotwierdzanie się idei nazywamy wolą, a rozum i wola tworzą według Spinozy jedność, tak jak ruch i spoczynek ${ }^{44}$. Jest to jedność potencjalności, której rzeczywistość polega na zrealizowaniu. Dlatego też najgłębsza istota każdej rzeczy tworzy własne dążenie do utrzymania swego istnienia, które w samym tylko duchu ujawnia się jako wola, a w duchu i ciele jednocześnie - jako popęd ${ }^{45} \mathrm{i}$ tak, jak pożądanie jest naturą, istotą wszelkich rzeczy ${ }^{46}$, tak również modus ludzki ma podstawę swego bytu w dążeniu samozachowawczym, podstawę dynamiczną, a nie statyczny grunt, zatem - w dążeniu samozachowawczym ma podstawę wszelkich cnót; cnota bowiem i możność jest dla etycznego dynamizmu Spinozy jednym i tym samym ${ }^{47}$.

Etyka oznacza dla filozofii potencjalności dynamikę afektów. Sensem etycznej nauki wychowania spinozyzmu jest doprowadzenie do przełamania

\footnotetext{
${ }^{39}$ Tamże, przyp. do tw. 44, s. $122-124$.

40 Tamże, przyp. do tw. 3, s. 68.

${ }^{41}$ Listy, wyd. cyt., Ep. 83, s. 341.

${ }^{42}$ B. de Spinoza, Pisma wczesne, Warszawa 2009, Traktat krótki o Bogu, człowieku i jego szczęśliwości [= TB], cz. I, rozdz. 9, s. 251-252; tamże, przyp. 7 do Przedmowy, [w:] TB, cz. II, s. 256; por. Etyka, cz. II, tw. pomocnicze I, s. 83.

${ }^{43}$ Etyka, cz. II, przyp. do tw. 43, s. 120.

${ }^{44}$ Tamże, dod. do tw. 49, s. 130.

45 Tamże, cz. III, przyp. do tw. 9, s. 154.

${ }^{46}$ Tamże, dow. do tw. 57, s. 210-211; por. tamże, tw. 7, s. 152 i przyp. do dow. tw. 9, s. 154.

${ }^{47}$ Tamże, tw. 9, s. 153-154.
} 
nieograniczoną potencją boskiego działania wszelkich ograniczonych możności.

Jeśli w decydujących, zasadniczych liniach deformacji substancjalność i potencjalność filozofii Spinozy ukazuje się jako autentyczna filozofia baroku, ukształtowana $\mathrm{z}$ tych samych konstytutywnych kategorii, co i sztuka Rembrandta, to i w szczegółach łatwo będzie rozpoznać rysy fizjonomii baroku. Skala potencjalności zakłada niuanse, psychologia jest jej najbardziej własnym obszarem. Spinoza pozostawił w swej nauce o afektach majstersztyk psychologiczny, który w miejsce nazewnictwa scholastycznego wprowadza dynamikę realnych doznań. Spinozjańska wiedza o duszy zna niuanse. Wie o kompleksowości afektów ${ }^{48}$ i rozumie działanie przekątnej w równoległoboku sił emocjonalnych.

Barok kształtuje organizmy tam, gdzie renesans składał mechanizmy. Spinoza jest głosicielem teorii organicznej, w której indywiduum składa się z części, o ile w ruchu i spoczynku staje się jednością ${ }^{49}$. Wprowadza pojęcie syntezy dynamicznej, które dopiero pozwala pojąć różnorodność jako jedność tam, gdzie wpierw istniała wielość tego, co mechaniczne. W ten sposób zdolny jest pojmować jako jedność charakter rzeczy jako organu, narządu organizmu ${ }^{50}$. Pomiędzy Hobbesem i Spinozą w dziedzinie filozofii polityki, między Descartes’em i Spinozą w metafizyce leży odstęp całego świata. Zaczęła się nowa epoka.

\section{is}

Początkowo brzmi to paradoksalnie, jeśli się powiada, że obydwaj, Rembrandt i Spinoza, byli wyrazem kontrreformacji, dopóki w kontrreformacji widzi się w istocie pewną reakcję katolicyzmu wobec ruchu protestanckiego. Naprawdę jednak kontrreformacja oznacza (wbrew nieszczęśliwie negatywnej nazwie) pewien całkowicie źródłowy ruch religijny, ostatni akt ożywienia chrześcijaństwa w pewnym, być może o wiele bardziej specyficznym, religijnym sensie, aniżeli religijny subiektywizm reformacji. Bóstwo, architettore del mondo dla renesansu, osoba dla reformacji, znów staje się nieskończonością, a z nieskończonością jednoczy się tęsknota religijna baroku. Religia

\footnotetext{
48 Tamże, tw. 59, dow. do dod. II, s. 207.

${ }^{49}$ Tamże, przyp. do tw. 59, s. 213-215.

50 Tamże, cz. II, tw. pomocnicze VII, s. 88-89.
} 
baroku, religia nieskończoności, która przeciwstawia się religii formowania, luteranizmowi i kalwinizmowi, poczyniła próbę rozwiązania, tak jak ją zaczęła mistyka hiszpańska, a systematyzował jezuityzm. Podczas gdy człowiek w ekstazie wykracza z siebie, jednoczy się z bóstwem, to, co skończone, wkracza w Nieskończone. Exercitia spiritualia św. Ignacego ukazały w tej postaci drogę religijnego spełnienia; sztuka El Greca stworzyła symbole tej ekstazy, gdy boskość emanuje w niej w kosmicznych wirach ku ziemi, gdy pozwala ona człowiekowi w magicznym przyciąganiu zdążać do tego, co nadziemskie. Tęsknota za nieskończonością kontrreformacji jako religii baroku przezwycięża w emanacji i ekstazie otchłań transcendencji. Ale barok umie rozwiązać jeszcze jedno zadanie religijne epoki: ono nie leży w obszarze transcendencji, lecz immanencji i dlatego jego droga nie jest drogą ekstazy, lecz drogą mistyki. Jeśli chce się odczuć najgłębsze pokrewieństwo Rembrandta ze Spinozą, trzeba go szukać w obszarze holenderskiej mistyki sekt. Zrodzony z ducha późnego gotyku neofityzm, z tego powodu antyprotestancki, dążący do nieskończoności, kształtuje podstawy protestanckiej kontrreformacji na Północy. W XVII wieku przeżywa on w Niderlandach drugi rozkwit, we wszystkich tych dążeniach, które sumują się w pojęciu reformatorów, a którego najbardziej znanym nam przykładem są kolegianci rijnsburscy. Pisma przyjaciół Spinozy, Pietera Ballinga i Jarriga Jellesa, to najbardziej wymowne świadectwa nowej religijności, której ostatecznym celem jest bezpośrednie zjednoczenie z bóstwem, nie mieszczącym się już w ograniczonej formie dogmatyki protestanckiej. Bóg jest tym, co ci najbliższe (Gott ist dir das Allernächste), uczy Balling w swej książeczce o świetle wewnętrznym. Pewien niemiecki protestant udaje się do Niderlandów i w trakcie dwuletnich studiów w Lejdzie (według świadectw późniejszych pism polemicznych) obraca się w neofickich i fanatycznych sektach. Jest to Anioł Ślązak, który doszedł do katolickiej kontrreformacji drogą niderlandzkiej mistyki sekciarskiej. Leibniz, który sam stał najbliżej tych spraw, najwcześniej rozpoznał głębokie wewnętrzne pokrewieństwo mistyki Cherubowego wędrowca i filozofii Spinozy. Po wyklęciu z synagogi Spinoza znalazł schronienie w kręgach Doopsgezni$d e n^{51^{*}}$, których radykalny odłam tworzyli właśnie kolegiaci, a jego młodzieńcza rozprawa, Traktat krótki, posługuje się nie tylko terminologią tego kręgu, lecz przepełniona jest również duchem niderlandzkiej mistyki sekciarskiej,

${ }^{51}$ * Doopsgezinden - mennonici, powstały w Niderlandach w XVI w. (zał. Menno Simmons; Fundamentbook, 1539, wykład podstawy wiary i organizacji gminy) odłam protestanckiego ugrupowania anabaptystów. 
która ratuje spadek gotyckiej mistyki Niemiec, przenosząc go na grunt niderlandzkiego baroku. Rembrandt, wychowany w religii Kalwina, stał się według świadectwa jego biografa, Baldinucciego, mennonitą. Podobnie jak Vandel musiał ratować barokowe przeżywanie swej sztuki poetyckiej, zagłębiając się w katolicyzmie, tak też i Rembrandt ze wspaniałą nieświadomością mógł tylko w mistyce neofitów znaleźć możliwość kształtowania zjednoczenia swej immanencji z Bogiem.

\section{is}

Spinozę dzieli od Rembrandta jedno pokolenie. Kiedy Spinoza się urodził, Rembrandt malował już Lekcję anatomii dr Nikolaesa Tulpa. Różnica pokolenia daje się najwyraźniej odczytać w ich stosunku do antyku.

Dla Rembrandta, najbardziej wykształconego z wszystkich malarzy (rozumiał łacinę, grekę i hebrajski), antyk oznaczał materiał, nie formę. W pokoleniu Spinozy staje się wyraźniejsze, że barok jest stylem dialektycznym, w którym tendencje renesansowego formowania kłócą się z gotycką tendencją nieskończoności. Antyk jest dla Spinozy daleko bardziej elementem formy jak dla Rembrandta. Spinoza wywodzi się nie tylko z holenderskiej mistyki sekciarskiej, lecz, jako uczeń Descartes’a, także z baroku francuskiego, którego klasycyzm nigdy nie wyrzekł się formowania renesansu. Spinoza przejmuje z filozofii niderlandzkiej naukę Stoi: religijna tęsknota jego barokowego odczuwania została uformowana przez idealny obraz mędrca stoickiego. Gdy szuka się źródeł religijności Spinozy, znajduje się je w tej samej głębi, jaką miała religia Rembrandta. Jednak gdy idzie o widzialność postaci ponadziemskich, filozofia Spinozy ma swój analogon w klasycystycznym w swej istocie baroku holenderskim, żywym w budowlach drugiej połowy XVII wieku. Być może kościół, w którego krypcie szczątki Spinozy złączyły się z ziemią, Nieuwe Kerk w Hadze, nie wyrósł z protestanckiej ciasnoty holenderskiej religii predykantów, lecz raczej jest wyrazem owej wolnej, chociaż umiarkowanej rozległości neutralizmu regentów, której duch odnalazł swój kształt w myśli państwowej Johanna de Witta i w Traktacie teologiczno-politycznym Spinozy, jest objawieniem jednego i tego samego ducha, który barokowej tęsknocie za nieskończonością ukazał drogę spełnienia w Spinozjańskiej Etyce. 